\title{
The utility of hematopoietic stem cell karyotyping in the diagnosis of de novo myelodysplastic syndromes
}

\author{
Manoj S. Bandara $^{1,2}$ • Hemali W. W. Goonasekera ${ }^{1}$ - Vajira H. W. Dissanayake ${ }^{1}$
}

Received: 12 May 2016 / Accepted: 18 September 2016/Published online: 30 September 2016

(C) Springer-Verlag Berlin Heidelberg 2016

\begin{abstract}
Myelodysplastic syndromes (MDS) are a clonal hematopoietic stem cell (HSC) disorders. Cytogenetics plays a vital role in pathogenesis, diagnosis, prognosis, and determining treatments in MDS. Cytogenetic studies on $\mathrm{CD} 34^{+}$cells in Asian MDS patients are limited. The aim of conducting this study was to compare the karyotypic features of $\mathrm{CD} 34^{+}$cells and their bone marrow (BM) karyotypes. BM samples of 20 primary MDS patients were collected. BM-CD $34^{+}$cells were isolated by CD34 positive selection. Conventional karyotyping was performed on primary BM samples and isolated CD $34^{+}$ cells. Fluorescence in situ hybridization (FISH) was performed to confirm del(5q) by using XL 5q31/5q33 locusspecific probe. Chromosomal abnormalities were detected in $41 \%(7 / 17)$ of BM and $40 \%(8 / 20)$ of HSC karyotypes. BM and HSC karyotypes were similar (94\%) except in one (BM-normal; CD 34+ cells had del(5q)) where the patient showed characteristic $\operatorname{del}(5 \mathrm{q})$ phenotype. The abnormalities found were $\operatorname{del}(5 q)-10 \%$ $(2 / 20), \operatorname{del}(11 \mathrm{q})-5 \%(1 / 20), \operatorname{del}(12 \mathrm{p})-5 \%(1 / 20)$, $47, \mathrm{XY},+19-5 \%(1 / 20)$, hypodiploidy-5\%(1/20), and random loss of chromosomes- $10 \%(2 / 20)$. The percentage of abnormal metaphases counted per case was higher for $\mathrm{CD} 34^{+}$cell cultures than for BM cultures. Culture
\end{abstract}

Electronic supplementary material The online version of this article (doi:10.1007/s12308-016-0283-6) contains supplementary material, which is available to authorized users.

Vajira H. W. Dissanayake vajirahwd@hotmail.com

1 Human Genetics Unit, Faculty of Medicine, University of Colombo, Kynsey Road, Colombo 8, Sri Lanka

2 Department of Pre-Clinical Sciences, General Sir John Kotelawala Defence University, Kandawala Road, Rathmalana, Sri Lanka failure were less for $\mathrm{CD} 34^{+}$cells when compared to BM. Sample limitation for BM does not apply for CD $34^{+}$cells if cultures can be maintained. Although the abnormal karyotypes counted were greater using CD $34^{+}$ cells than $\mathrm{BM}$, there was no statistically significant difference $(p>0.05)$. Detection of karyotypic abnormalities could be greater when using CD $34^{+}$cells. All the karyotypic abnormalities reported in this study had been previously known in MDS. Further large scale studies are needed to verify our findings.

Keywords Cytogenetic abnormality $\cdot$ Myelodysplastic syndromes $\cdot$ Hematopoietic stem cells $\cdot$ Bone marrow $\cdot$ FISH

\section{Introduction}

Myelodysplastic syndromes (MDS) comprise a group of hematopoietic stem cell disorders characterized by peripheral cytopenias, bone marrow dysplasia with ineffective hematopoiesis [1]. Cytogenetics have long been known to determine the pathogenesis, diagnosis, and prognosis and determine treatment in MDS.

An International Prognostic Scoring System (IPSS) was proposed in 1997 to improve the risk assessment of MDS, based on cytogenetic abnormalities, bone marrow blast percentage, cytopenias, and patient variable age and gender with MDS [2]. This system was re-evaluated in 2012 and a new scoring system for MDS was defined; the revised IPSS-RIPSS [3]. The R-IPSS recognizes five cytogenetic sub groups [3]. Cytogenetic abnormalities are found in $40-50 \%$ of cases of MDS by conventional karyotype [4]. The commonest recurring cytogenetic abnormalities in MDS include $+8, \operatorname{del}(5 q)$, $\operatorname{del}(7 q), \operatorname{del}(20 q), \operatorname{del}(11 q)$ and $-Y$ [5]. The cytogenetic features of MDS have shown a significant difference among 
Asian populations compared to the Western populations [6-14].

MDS result from malignant transformation of a hematopoietic stem cell (HSC), which has growth advantage over normal CD $34^{+}$cells resulting in clonal expansion [15]. Molecular and cytogenetic abnormalities are major determinants in transforming normal CD $34^{+}$cells to malignant cells in the bone marrow (BM) [16-18]. Cytogenetic analyses on hematological malignancies have identified various clonal chromosomal abnormalities in the haematopoeitic stem/ progenitors as well as in the myeloid and lymphoid lineages of blood cells [19-24]. However, the cell of origin of the cytogenetic abnormalities in MDS is still debatable. The aim of this research was to conduct a pilot study to investigate the cytogenetic abnormalities of $\mathrm{CD} 34^{+}$cells of primary MDS patients and compare them with BM karyotypes. In addition, this is the first cytogenetic analysis to describe chromosomal abnormalities of patients with primary MDS in Sri Lanka.

\section{Materials and methods}

\section{Patients}

Twenty BM samples of the patients diagnosed as MDS were collected during the 2 years (2013 to 2015) of patient recruitment conducted at four tertiary care hospitals in Sri Lanka (National Hospital of Sri Lanka, Colombo South Teaching Hospital, Colombo North Teaching Hospital and National Cancer Institute, Maharagama) after obtaining written informed consent. The study was conducted according to the principles of Declaration of Helsinki (2008). Ethical approvals for the study were obtained from the ethics review committees of the Faculty of Medicine, University of Colombo, Sri Lanka and the above named hospitals. Patients with secondary MDS were excluded. Patient's clinical data and investigation data were recorded in an interviewer administered questionnaire. Patient characteristics are given in Table 1. All patients were diagnosed as MDS and subtyped according to the WHO classification.

\section{Isolation of $\mathrm{CD34}^{+}$cells}

From the BM samples, mononuclear cells were purified by Histopaque (Sigma-Aldrich, Gillingham, UK) density gradient centrifugation and labeled with CD34 MicroBeads (EasySep CD34 selection kit, StemCell Technologies, Canada), and were isolated using magnetic cell separation. The purity of $\mathrm{CD} 34^{+}$cell population was evaluated by flow cytometry (FACScan; Becton Dickinson, Heidelberg, Germany) and was $90 \%$ or greater (See Supplemental Data Figure S1).

\section{Cytogenetic analysis of BM}

BM was cultured in marrow max media (Gibco, USA) at a concentration of $2 \times 10^{6}$ cells per $\mathrm{ml}$ and incubated for $24 \mathrm{~h}$ at $37^{\circ} \mathrm{C}$. Cells were arrested with colcemid $(0.01 \mathrm{mg} / \mathrm{ml})$ for $2 \mathrm{~h}$ before harvesting. Cells were harvested and treated with $0.075 \mathrm{M} \mathrm{KCl}$ for $20 \mathrm{~min}$ at $37{ }^{\circ} \mathrm{C}$. Cells were fixed with freshly prepared fixative (methanol/acetic acid 3:1 v/v). Chromosomal spreads for analysis were prepared by dropping onto slides at 76-82\% humidity and Giemsa Trypsin Giemsa (GTG) banding was performed. At least 10-20 metaphases were counted for structural and numerical chromosomal abnormalities and 10 were analyzed. The karyotypes were described according to the International System for Human Cytogenetic Nomenclature (ISCN) [25] and reported according to the association for clinical cytogenetics, professional guidelines for clinical cytogenetics, acute myeloid leukemia and MDS (2012) v1.00 [26]. The number of metaphases analyzed to report a normal karyotype for BM was 10. Presence of an abnormal clone was ascertained by the observation of more than two metaphase spreads having the same structural rearrangement or chromosomal gain. Chromosomal loss had to be observed in at least three cells, to confirm an abnormal clone.

\section{Cytogenetic analysis of $\mathrm{CD}^{+} 4^{+}$cells}

CD $34^{+}$cells were cultured at a concentration of $1.0 \times 10^{4}$ cells $/ \mathrm{ml}$ in RPMI 1640 media supplemented with $20 \%$ fetal calf serum (FCS; Invitrogen, Australia), $20 \mathrm{ng} / \mathrm{mL}$ thrombopoietin (R \&D, USA), $20 \mathrm{ng} / \mathrm{mL}$ FLT3 ligand (R7D, USA), $50 \mathrm{ng} / \mathrm{mL}$ stem cell factor and $50 \mathrm{ng} / \mathrm{mL}$ IL6. Cells were incubated for 24 to $72 \mathrm{~h}$ at $37{ }^{\circ} \mathrm{C}$. One hundred and fifty microliters of colcemid was added $2 \mathrm{~h}$ before harvesting. Cell harvesting and GTL banding were performed as described above for the $\mathrm{BM}$ cells and $\mathrm{CD} 34^{+}$cells. The karyotypes were classified according to the ISCN guidelines.

\section{Fluorescence in situ hybridization (FISH)}

$\mathrm{BM}$ and $\mathrm{CD} 34^{+}$cells of patients suspected for having del (5q) based on their BM findings were subjected to FISH analysis. XL 5q31/5q33 locus-specific probe (Metasystems, USA) was used according to the manufacturer's protocol. Briefly, $500 \mu \mathrm{L}$ of $\mathrm{BM}$ was added to $10 \mathrm{~mL}$ of $\mathrm{KCl}$ and left for $20 \mathrm{~min}$ at room temperature. Next, $500 \mu \mathrm{L}$ of fixative (methanol/acetic acid 3:1 v/v) was added and spun at $1500 \mathrm{rpm}$ for $8 \mathrm{~min}$, and supernatant was removed. Ten milliliters of the same fixative was added to the pellet, mixed and spun $1500 \mathrm{rpm}$ for $8 \mathrm{~min}$. A cell smear was prepared and the slide was kept for $15 \mathrm{~min}$ at room temperature to dry. Ten microliters of probe was added to the slide and kept for overnight hybridization. After hybridization, the slides were washed in 


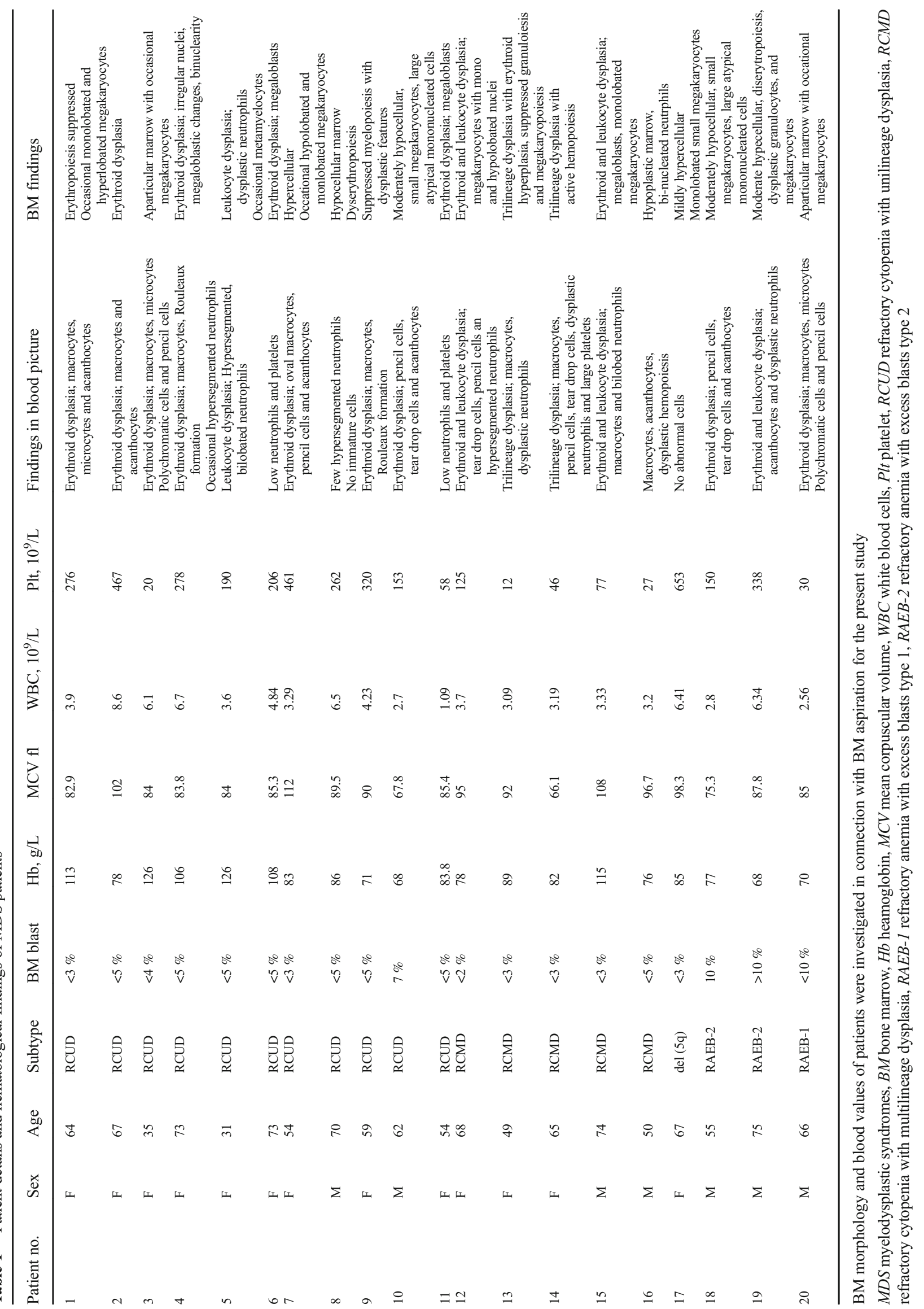


$0.4 \% \mathrm{SSC}$ for $2 \mathrm{~min}$ at $72{ }^{\circ} \mathrm{C}$, followed by a washes in $0.05 \%$ Tween 20 in $2 \% \mathrm{SSC}$ for $30 \mathrm{~s}$ and distilled water at room temperature and counterstaining with DAPI [(4',6-diamidino2-phenylindole), $1 \mathrm{mg} / \mathrm{mL}$; Sigma]. One hundred nuclei were individually analyzed by two individuals per each sample. The cutoff level for $1 \mathrm{O}+1 \mathrm{G}$ signal greater than $5 \%$ was considered as positive for $\operatorname{del}(5)(\mathrm{q} 31.2 \mathrm{q} 33)$.

\section{Statistical analysis}

$t$ test was used to compare the mean differences of abnormal metaphases of $\mathrm{CD} 34^{+}$cells and BM karyotypes. The statistical significance of the results was considered at $(p<0.05)$.

\section{Results}

\section{Patient characteristics}

The age group ranged from 31 to 75 years with the median age of 67 years. The majority $(n=13,65 \%)$ were women. On peripheral blood counts and morphology and BM morphology, the following subtypes were identified prior to karyotyping (Table 1). Refractory anemia with excess blasts1 (RAEB-1) was diagnosed in 1 patient, refractory anemia with excess blasts-2 (RAEB-2) was diagnosed in 2 patients, refractory cytopenia with multilineage dysplasia (RCMD) was diagnosed in 5 patients, MDS with isolated del(5q) was diagnosed in 2 patients and 11 patients were diagnosed with refractory cytopenia with unilineage dysplasia (RCUD).

\section{Cytogenetic analysis of BM}

Of the 20 patients analyzed, $10(50 \%)$ had normal karyotypes and $7(35 \%)$ had single chromosomal abnormalities including del (5q), del (11q), del (12p) and trisomy 19 (See Supplemental Data Figure S2). BM cultures of 3 (15\%) patients did not grow to obtain in any analyzable metaphase spreads (Table 2). The percentages of metaphase cells having chromosomal abnormalities are given in Table 4. Distribution of clonal abnormalities in the MDS subtypes other than del (5q) were; RCUD $36 \%$ (4/11) including random chromosomal losses in two cases, hypodiploidy and del (11q) in one case each; RCMD $44 \%(2 / 5)$ which included del (12p) and $47, \mathrm{XY},+19$ in 1 case each (Table 3 ). Both RAEB-2 cases did not have an analyzable spreads. The patient no. 17 showed $\operatorname{del}(5)(q 14 q 34)$ in $50 \%$ of the metaphase cells in the BM karyotype. In FISH analysis of BM, $80 \%$ of the cells showed deletion of 5q31.2 and 5q32-33(See Supplemental Data Figure S3). The percentage of abnormal metaphase counts in each patient is given in Table 4 .

\section{Cytogenetic analysis of $\mathrm{CD}^{+} 4^{+}$cells}

The cytogenetic abnormalities of $\mathrm{CD} 34^{+}$cells were similar (94\%) to those of BM except in one case. Patient no. 7 (Table 2) who did not show any chromosomal abnormalities on BM karyotype (See Supplemental Data Figure S4 A) however showed del $(5 q)$ in HSC karyotype (See Supplemental Data Figure S4 B). The abnormality was detected in $62 \%$ of the HSC metaphases confirmed by FISH analysis where $62 \%$ of the cells showed deletion of 5q31.2 and 5q32-33(See Supplemental Data Figure S4 C). Detailed karyotypes of $\mathrm{CD} 34^{+}$cells are shown in Table 2 and percentages of metaphase cells shown the chromosomal abnormalities are given in Table 4. Patient no. 17 who also had del(5q) in BM exhibited deletion of $5 \mathrm{q} 31.2$ and $5 \mathrm{q} 32-33$ in $80 \%$ of HSC metaphases in FISH analysis. The metaphase counts for $\mathrm{CD} 34^{+}$cells were higher than that of BM but there was no statistically significant difference between the two.

\section{Discussion}

MDS is a rare disease in blood and BM with the incidence rate of 4.6 per 100,000 inhabitants of population in USA [27] and the incidence rate of MDS in Japan is 3.8 cases per 100,000 for men and 2.4 cases per 100,000 for women [28]. The incidence rate of MDS in Sri Lanka is not known and according to the latest publication of National Cancer Registry published by the Ministry of Health, Sri Lanka, 69 MDS patients have been reported in the year of 2007 [29]. Accordingly, the estimated incidence rate of MDS in Sri Lanka is nearly 4 per $1,000,000$ (one million) people. We conducted the patient recruitment for 2 years (2013 to 2015) from four tertiary care hospitals in Sri Lanka (National Hospital of Sri Lanka, Colombo South Teaching Hospital, Colombo North Teaching Hospital and National Cancer Institute, Maharagama). We collected 20 BM samples for this study which we believe as a representative sample of Sri Lankan MDS population.

In this study, we describe the cytogenetic features of BM and CD $34^{+}$cells of patients with primary MDS in Sri Lanka. The frequency of cytogenetic abnormalities of MDS patients in this study was $41 \%$. The reported frequency of chromosomal abnormalities in Caucasians using conventional cytogenetics is $40-70 \%$ [10]. The frequencies reported in Asian populations is as follows: $39 \%$ in China, $50 \%$ in Taiwan, $44.1 \%$ in Thailand, $44 \%$ in Korea, $53 \%$ in Japan, 47.5 and $54.48 \%$ in India, and $42.3 \%$ in Pakistan [6-13]. The frequency of chromosomal abnormalities in our study group of Sri Lankan MDS patients is consistent with the reported data on Asian populations.

In our study, a range of chromosomal aberrations, including del (5q), del (11q), del (12p) and trisomy 19 
Table 2 Patient details, hematological and cytogenetic findings of MDS patients

\begin{tabular}{|c|c|c|c|}
\hline Patient no & Subtype & Karyotype in BM & Karyotype in HSC \\
\hline 1 & RCUD & $46, \mathrm{XX}[12]$ & $46, \mathrm{XX}[7]$ \\
\hline 2 & RCUD & Hypodiploidy [6] & Hypodiploidy [7] \\
\hline 3 & RCUD & Random chromosomal losses [12] & Random chromosomal losses [14] \\
\hline 4 & RCUD & $46, \mathrm{XX}[11]$ & $46, \mathrm{XX}[6]$ \\
\hline 5 & RCUD & Random chromosomal losses [16] & Random chromosomal losses [8] \\
\hline 6 & RCUD & $46, X X[16]$ & $46, \mathrm{XX}[11]$ \\
\hline 7 & RCUD & $46, \mathrm{XX}[11]$ & $46, X X, \operatorname{del}(5)(q 14 q 34)[5 / 8][127 / 200]^{*}$ \\
\hline 8 & RCUD & Failed & $46, \mathrm{XX}[7]$ \\
\hline 9 & RCUD & $46, \mathrm{XX}, \operatorname{del}(11)(\mathrm{q} 22 \mathrm{q} 23)[7 / 16]$ & 46,XX,del(11)(q22q23) [6/8] \\
\hline 10 & RCUD & $46, \mathrm{XY}[15]$ & $46, \mathrm{XY}[8]$ \\
\hline 11 & RCUD & $46, \mathrm{XX}[11]$ & $46, \mathrm{XX}[6]$ \\
\hline 12 & RCMD & $46, \mathrm{XX}[11]$ & $46, \mathrm{XX}[7]$ \\
\hline 13 & RCMD & $46, \mathrm{XX}, \operatorname{del}(12)(\mathrm{p} 13)[3 / 10]$ & $46, \mathrm{XX}, \operatorname{del}(12)(\mathrm{p} 13)[3 / 8]$ \\
\hline 14 & RCMD & $46, \mathrm{XX}[10]$ & $46, \mathrm{XX}[6]$ \\
\hline 15 & RCMD & $46, \mathrm{XY}[14]$ & $46, \mathrm{XY}[8]$ \\
\hline 16 & RCMD & $47, X Y,+19[6 / 10]$ & $47, \mathrm{XY},+19[5 / 8]$ \\
\hline 17 & $\operatorname{del}(5 q)$ & 46,XX,del(5)(q14q34) [6/12] [98/200]* & 46,XX,del(5)(q14q34) [163/200]* \\
\hline 18 & RAEB-2 & Failed & $46, X Y[4]$ \\
\hline 19 & RAEB-2 & Failed & $46, X Y[8]$ \\
\hline 20 & RAEB-1 & $46, X Y[14]$ & $46, X Y[9]$ \\
\hline
\end{tabular}

$M D S$ myelodysplastic syndromes, $B M$ bone marrow, $R C U D$ refractory cytopenia with unilineage dysplasia, $R C M D$ refractory cytopenia with multilineage dysplasia, $R A E B-1$ refractory anemia with excess blasts type 1, RAEB-2 refractory anemia with excess blasts type 2 , [ ] \% of metaphases with the aberration, [ ]* number of cells with the aberration/the number of cells analyzed in FISH

were found. In addition, random losses of chromosomes and hypodiploidy were also detected. FISH was performed to confirm del(5q) by using XL 5q31/5q33 locus-specific probe. This probe detects deletions in the long arm of chromosome 5 (https://metasystemsprobes.com/en/probes/xl/d-5042-100-og/). The orange labeled probe detects a region at $5 \mathrm{q} 32$ which includes EGR1 and CDC25C genes (https://metasystems-probes.
Table 3 Type of chromosome abnormalities in MDS subtypes

\begin{tabular}{|c|c|c|c|c|c|c|}
\hline \multirow{2}{*}{$\begin{array}{l}\text { WHO } \\
\text { subgroup }\end{array}$} & \multicolumn{3}{|l|}{ Karyotype in BM } & \multicolumn{3}{|l|}{ Karyotype in HSC } \\
\hline & Chromosomal abnormality & No. & $\begin{array}{l}\text { Total } \\
(\%)\end{array}$ & Chromosomal abnormality & No. & $\begin{array}{l}\text { Total } \\
(\%)\end{array}$ \\
\hline \multirow[t]{4}{*}{ RCUD } & Hypodiploidy & 1 & & Hypodiploidy & 1 & \\
\hline & $\begin{array}{l}\text { Random chromosomal } \\
\text { losses }\end{array}$ & 2 & $4(20)$ & $\begin{array}{l}\text { Random chromosomal } \\
\text { losses }\end{array}$ & 2 & $5(25)$ \\
\hline & 46,XX,del (11)(q22q23) & 1 & & 46,XX,del (11)(q22q23) & 1 & \\
\hline & & & & $46, X X, \operatorname{del}(5)(q 14 q 34)$ & 1 & \\
\hline \multirow[t]{2}{*}{ RCMD } & $46, \mathrm{XX}, \operatorname{del}(12)(\mathrm{p} 13)$ & 1 & $2(10)$ & $46, \mathrm{XX}, \operatorname{del}(12)(\mathrm{p} 13)$ & 1 & $2(10)$ \\
\hline & $47, \mathrm{XY},+19$ & 1 & & $47, \mathrm{XY},+19$ & 1 & \\
\hline RAEB-1 & - & - & - & - & - & - \\
\hline RAEB-2 & - & - & - & - & - & - \\
\hline $\operatorname{del}(5 q)$ & 46,XX del(5)(q14q34) & 1 & $1(5)$ & 46,XX del(5)(q14q34) & 1 & $1(5)$ \\
\hline
\end{tabular}

$M D S$ myelodysplastic syndromes, $B M$ bone marrow, $R C U D$ refractory cytopenia with unilineage dysplasia, $R C M D$ refractory cytopenia with multilineage dysplasia, $R A E B-1$ refractory anemia with excess blasts type 1 , $R A E B-2$ refractory anemia with excess blasts type 2 
Table 4 Cytogenetic alterations in sorted HSCs and whole BM populations

\begin{tabular}{|c|c|c|c|c|c|}
\hline \multirow[t]{2}{*}{ Patient No } & \multirow[t]{2}{*}{ Subtype } & \multicolumn{2}{|l|}{ BM karyotype } & \multicolumn{2}{|l|}{ HSC karyotype } \\
\hline & & Karyotype & $\begin{array}{l}\text { Abnormality in metaphase } \\
\text { cells, } \%\end{array}$ & Karyotype & $\begin{array}{l}\text { Abnormality in } \\
\text { metaphase cells, } \%\end{array}$ \\
\hline 7 & RCUD & $46, X X$ & 0 & $46, X X, \operatorname{del}(5)(q 14 q 34)$ & 62 \\
\hline 9 & RCUD & 46,XX,del(11)(q22q23) & 44 & $46, X X, \operatorname{del}(11)(\mathrm{q} 22 \mathrm{q} 23)$ & 75 \\
\hline 13 & RCMD & 46,XX,del(12)(p13) & 30 & $46, \mathrm{XX}, \operatorname{del}(12)(\mathrm{p} 13)$ & 38 \\
\hline 16 & RCMD & $47, \mathrm{XY},+19$ & 60 & $47, X Y,+19$ & 65 \\
\hline 17 & $\operatorname{del}(5 q)$ & 46,XX,del(5)(q14q34) & $50^{\mathrm{a}}$ & $46, X X, \operatorname{del}(5)(q 14 q 34)$ & $80^{\mathrm{a}}$ \\
\hline
\end{tabular}

$M D S$ indicates myelodysplastic syndromes, $B M$ bone marrow, $R C U D$ refractory cytopenia with unilineage dysplasia, $R C M D$ refractory cytopenia with multilineage dysplasia

a $\%$ calculated according to FISH data

com/en/probes/xl/d-5042-100-og/). The green labeled probe specifically detects $5 \mathrm{q} 32-33$ region of the RPS14 gene (https://metasystems-probes.com/en/probes/xl/d$5042-100-\mathrm{og} /)$. One green $(1 \mathrm{G})$ and one orange (1O) signal indicates deletions of both loci in $5 \mathrm{q} 31.2$ and $5 \mathrm{q} 33$ (https://metasystems-probes.com/en/probes/xl/d5042-100-og/).

A study conducted on a large Caucasian MDS population showed that interstitial deletions of the long arm of chromosome 5 [del $(5 q)]$ with or without additional karyotypic abnormalities is the most frequent abnormality seen in MDS [10]. The common cytogenetic abnormalities found in Asian MDS population include trisomy $8,-20 / \mathrm{del} 20 \mathrm{q},-5 / \mathrm{del} 5 \mathrm{q},-21$ and $-7 /$ del $7 q$ and others included complex karyotypes $[6-9,11]$. Of the countries in the South Asian region, a study from India reports monosomy 7 as the most frequent cytogenetic abnormality seen in MDS patients in India while another study recognizes del(5), del(7) and trisomy 8 as main abnormalities detected $[11,12]$. These studies indicate that del $5 \mathrm{q}$ is not the most prevalent cytogenetic abnormality in Asian countries in contrast to that reported in Western MDS patients. The cytogenetic findings in our study confirm previously reported chromosomal abnormalities associated with MDS. Hypodiploidy has not been reported as a common cytogenetic aberration of MDS; however, few studies have described its association with MDS [30]. Although monosomy 7 and trisomy 8 have been reported to be common among Asian populations, our patient group did not have them. The highest number of chromosomal abnormalities was found in RAEB2 followed by RAEB-1 patients [14].

Cytogenetic analysis of stem cells in MDS not only should help to understand the pathogenesis of MDS, but also could shed the light on therapeutic implications. Previous studies on cytogenetic analysis have shown conflicting results on the origin of cytogenetic abnormalities in the hematopoietic hierarchy [23, 31-37]. Some studies have revealed that the cytogenetically aberrant cells in MDS are constrained to myeloid and erythroid lineages and, rarely, megakaryocytic lineages [31-36] while others report an association of a multipotential stem cell [37]. The underline basis for these contradictory results is not yet clear but may be due to different methods used to evaluate clonality and detect cytogenetic abnormalities. The variability between patients can also affect the cytogenetic analysis. If cytogenetic abnormalities in MDS arise at the HSC level, the CD $34^{+}$cells should share the same cytogenetic abnormalities as in the BM. Our findings confirm this theory as we observed similar $(94 \%)$ cytogenetic abnormalities in both BM and CD $34^{+}$cells.

An important finding of our study was the detection of del (5q) in CD $34^{+}$cells which was undetected by BM karyotype. This patient had del(5q) phenotype; 54-year-old female with high MCV and (BM) megakaryocytes moderately increased, showing hypolobated nuclei. Reason for the normal karyotype in this patient can be due to either failure of the abnormal clone to expand in cell culture or the number of cells expanded was not sufficient enough to detect the abnormality. We can infer the cytogenetic abnormalities present with low cell numbers may go undetected by BM karyotyping, but can be detected by karyotyping the CD $34^{+}$ cells.

The percentages of cytogenetically abnormal cells in BM $(46 \%)$ were less than those of $\mathrm{CD} 34^{+}$cells $(62 \%)$ in all patients showed chromosomal abnormalities $(p>0.05)$. A previous study on MDS patients with $-7 / 7$ q reports the presence of chromosomal abnormality in a greater proportion in CD $34^{+}$cells, (CD $34^{+}$cells $92 \%$ and BM cells $60 \%$ ) [38].

In conclusion, this is the first study to report the cytogenetic abnormalities of MDS patients in Sri Lanka. Also the detection of karyotypic abnormalities could be greater when using $\mathrm{CD} 34^{+}$cells. This suggests the possibility of incorporation of HSC karyotyping to the diagnostic work up of primary MDS patients with normal karyotypes. This could be validated in further studies with higher patient numbers. 
Acknowledgments This research was funded by the University Grants Commission of Sri Lanka. We would like to thank for the staff of the Human Genetics Unit, Faculty of Medicine, University of Colombo, Sri Lanka, National Hospital of Sri Lanka, Colombo 10, Colombo South Teaching Hospital, Kalubowila, Colombo North Teaching Hospital, Ragama and the National Cancer Institute, Maharagama, Sri Lanka and consultant hematologists.

\section{Compliance with ethical standards}

Conflict of interest The authors declare that they have no conflict of interest.

\section{References}

1. Heaney ML, Golde DW (1999) Myelodysplasia. N Engl J Med 340:1649-1660

2. Greenberg P, Cox C, LeBeau MM, Fenaux P, Morel P, Sanz G, Sanz M, Vallespi T, Hamblin T, Oscier D, Ohyashiki K, Toyama K, Aul C, Mufti G, Bennett J (1997) International scoring system for evaluating prognosis in myelodysplastic syndromes. Blood 89:2079-2088

3. Schanz J, Tüchler H, Solé F, Mallo M, Luño E, Cervera J, Granada I, Hildebrandt B, Slovak ML, Ohyashiki K, Steidl C, Fonatsch C, Pfeilstöcker M, Nösslinger T, Valent P, Giagounidis A, Aul C, Lübbert M, Stauder R, Krieger O, Garcia-Manero G, Faderl S, Pierce S, Le Beau MM, Bennett JM, Greenberg P, Germing U, Haase D (2012) New comprehensive cytogenetic scoring system for primary myelodysplastic syndromes (MDS) and oligoblastic acute myeloid leukemia after MDS derived from an international database merge. J Clin Oncol 30:820-829

4. Solé F, Luño E, Sanzo C, Espinet B, Sanz GF, Cervera J, Calasanz MJ, Cigudosa JC, Millà F, Ribera JM, Bureo E, Marquez ML, Arranz E, Florensa L (2005) Identification of novel cytogenetic markers with prognostic significance in a series of 968 patients with primary myelodysplastic syndromes. Hematologica 90:1168-1178

5. Otney HJ, Le Beau MM (2001) The cytogenetics of myelodysplastic syndromes. Best Pract Res Clin Haematol $1: 479-495$

6. Tien HF, Wang CH, Chuang SM, Chow JM, Lee FY, Liu MC, Chen YC, Shen MC, Lin DT, Lin KH (1994) Cytogenetic studies, ras mutation, and clinical characteristics in primary myelodysplastic syndrome a study on 68 Chinese patients in Taiwan. Cancer Genet Cytogenet 74:40-49

7. Intragumtornchai $\mathrm{T}$, Prayoonwiwat $\mathrm{W}$, Swasdikul D, Suwanwela N, Chaimongkol B, Jootar S, Chansung K, Chancharunee S, Leelasiri A, Yoshida Y (1997) Myelodysplastic syndrome in Thailand: a retrospective pathologic and clinical analysis of 117 cases. Leuk Res 21(suppl 1):S5

8. Lee JH, Shin YR, Lee JS, Kim WK, Chi HS, Park CJ, Seo EJ, Lee KH (2003) Application of different prognostic scoring systems and comparison of the FAB and WHO classifications in Korean patients with myelodysplastic syndrome. Leukemia 17:305-313

9. Matsushima T, Handa H, Yokohama A, Nagasaki J, Koiso H, Kin Y, Tanaka Y, Sakura T, Tsukamoto N, Karasawa M, Itoh K, Hirabayashi H, Sawamura M, Shinonome S, Shimano S, Miyawaki S, Nojima Y, Murakami H (2003) Prevalence and clinical characteristics of myelodysplastic syndrome with bone marrow eosinophilia or basophilia. Blood 101:3386-3390

10. Haase D, Germing U, Schanz J, Pfeilstöcker M, Nösslinger T, Hildebrandt B, Kundgen A, Lübbert M, Kunzmann R, Giagounidis AA, Aul C, Trümper L, Krieger O, Stauder R,
Müller TH, Wimazal F, Valent P, Fonatsch C, Steidl C (2007) New insights into the prognostic impact of the karyotype in MDS and correlation with subtypes: evidence from a core dataset of 2124 patients. Blood 110:4385-4395

11. Vundinti BR, Kerketta L, Jijina F, Ghosh K (2009) Cytogenetic study of myelodysplastic syndrome from India. Indian J Med Res 130:155-159

12. Chaubey R, Sazawal S, Dada R, Mahapatra M, Saxena R (2011) Cytogenetic profile of Indian patients with de novo myelodysplastic syndromes. Indian J Med Res 134:452-457

13. Xiao Y, Wei J, Chen Y, Zhang K, Zhou J, Zhang Y (2012) Trisomy 8 is the most frequent cytogenetic abnormality in de novo myelodysplastic syndrome in China. Onkologie 35:100-106

14. Rashid A, Khurshid M, Shaikh U, Adil S (2014) Chromosomal abnormalities in primary myelodysplastic syndrome. J Coll Physicians Surg Pak 24:632-635

15. Anastasi J, Feng J, Le Beau MM, Larson RA, Rowley JD, Vardiman JW (1993) Cytogenetic clonality in myelodysplastic syndromes studied with fluorescence in situ hybridization: lineage, response to growth factor therapy, and clone expansion. Blood 81:1580-1585

16. Jamieson CH, Gotlib J, Durocher JA, Chao MP, Mariappan MR, Lay M, Jones C, Zehnder JL, Lilleberg SL, Weissman IL (2006) The JAK2 V617F mutation occurs in haematopoietic stem cells in polycythemia vera and predisposes toward erythroid differentiation. Proc Natl Acad Sci U S A 103:6224-6229

17. Sloand E, Kim S, Fuhrer M, Risitano A, Nakamura R, Maciejewski JP, Barrett AJ, Young NS (2002) Fas-mediated apoptosis is important in regulating cell replication and death in trisomy 8 haematopoietic cells but not in cells with other cytogenetic abnormalities. Blood 100:4427-4432

18. Okuda T, Yokota S, Maekawa T, Sonoda Y, Taniwaki M, Misawa S, Takino T, Abe T (1988) Clonal involvement of granulocytemacrophage and erythroid lineages in a patient with refractory anaemia. Acta Haematol 80:110-115

19. Mehrotra BB, GeorgeTI KK, Avet-Loiseau H, Moore D II, Willman CL, Slovak ML, Atwater S, Head DR, Pallavicini MG (1995) Cytogenetically aberrant cells in the stem cell compartment (CD34 + lin-) in acute myeloid leukemia. Blood 86:1139-1147

20. Fagioli F, Cuneo A, Carli MG, Bardi A, Piva N, Previati R, Rigolin GM, Ferrari L, Spanedda R, Castoldi G (1993) Chromosome aberrations in CD34-positive acute myeloid leukemia. Correlation with clinicopathologic features. Cancer Genet Cytogenet 71:119-124

21. Haase D, Feuring-Buske M, Könemann S, Fonatsch C, Troff C, Verbeek W, Pekrun A, Hiddemann W, Wörmann B (1995) Evidence for malignant transformation in acute myeloid leukemia at the level of early haematopoietic stem cells by cytogenetic analysis of CD34+ subpopulations. Blood 15:2906-2912

22. Nilsson L, Astrand-Grundström I, Anderson K, Arvidsson I, Hokland P, Bryder D, Kjeldsen L, Johansson B, HellströmLindberg E, Hast R, Jacobsen SE (2002) Involvement and functional impairment of the CD34(+)CD38(-) Thy-1(+) haematopoietic stem cell pool in myelodysplastic syndromes with trisomy 8. Blood 100:259-267

23. Jaju RJ, Jones M, Boultwood J, Kelly S, Mason DY, Wainscoat JS, Kearney L (2000) Combined immunophenotyping and FISH identifies the involvement of B-cells in 5q-syndrome. Genes Chromosomes Cancer 29:276-280

24. Braulke F, Schanz J, Jung K, Shirneshan K, Schulte K, Schuetze C, Steffens R, Trümper L, Haase D (2010) FISH analysis of circulating $\mathrm{CD} 34+$ cells as a new tool for genetic monitoring in MDS: verification of the method and application to 27 MDS patients. Leuk Res 34:1296-1301

25. Shaffer LG, McGowan-Jordan J, Schmid M (2013) ISCN 2013: an international system for human cytogenetic nomenclature. Karger, Basel 
26. The Association of Clinical Cytogeneticists (ACC) Professional Standards Committees (2012) Professional guidelines for clinical cytogenetics; association for clinical cytognetics; acute myeloid leukemia \& myelodysplastic syndromes (V1.00)

27. Sekeres MA (2010) The epidemiology of myelodysplastic syndromes. Hematol Oncol Clin N Am 24:287-294

28. Chihara D, Ito H, Katanoda K, Shibata A, Matsuda T, Sobue T, Matsuo K (2014) Incidence of myelodysplastic syndrome in Japan. J Epidemiol 24:469-473

29. Cancer Incidence Data: Sri Lanka Year 2007. Ministry of Health, Sri Lanka. Available at http://www.health.gov. 1k/en/publication/cancer/Cancer\%20Registry\%202007\%20 final\%20version.pdf

30. Knuutila S, Teerenhovi L, Borgström GH (1984) Chromosome instability is associated with hypodiploid clones in myelodysplastic syndromes. Hereditas 101:19-30

31. Haase D, Feuring-Buske M, Schafer C, Schoch C, Troff C, Gahn B, Hiddemann W, Wörmann B (1997) Cytogenetic analysis of CD34+ subpopulations in AML and MDS characterized by the expression of CD38 and CD117. Leukemia 11:674-679

32. Nilsson L, Astrand-Grundstrom I, Arvidsson I, Jacobsson B, Hellstrom-Lindberg E, Hast R, Jacobsen SE (2000) Isolation and characterization of haematopoietic progenitor/stem cells in $5 \mathrm{q}-$ deleted myelodysplastic syndromes: evidence for involvement at the haematopoietic stem cell level. Blood 96:2012-2021

33. Nilsson L, Astrand-Grundstrom I, Anderson K, Arvidsson I, Hokland P, Bryder D, Kjeldsen L, Johansson B, Hellström-
Lindberg E, Hast R, Jacobsen SE (2002) Involvement and functional impairment of the CD34(+)CD38(-)Thy-1(b) haematopoietic stem cell pool in myelodysplastic syndromes with trisomy 8. Blood 100:259-267

34. Abrahamson G, Boultwood J, Madden J, Kelly S, Oscier DG, Rack K, Buckle VJ, Wainscoat JS (1991) Clonality of cell populations in refractory anaemia using combined approach of gene loss and Xlinked restriction fragment length polymorphism-methylation analyses. Brit J Haematol 79:550-555

35. Bernell P, Jacobsson B, Nordgren A, Hast R (1996) Clonal cell lineage involvement in myelodysplastic syndromes studied by fluorescence in situ hybridization and morphology. Leukemia 10:662-668

36. Boultwood J, Wainscoat JS (2001) Clonality in the myelodysplastic syndromes. Int J Hematol 73:411-415

37. Kuo YH, Landrette SF, Heilman SA, Perrat PN, Garrett L, Liu PP, Le Beau MM, Kogan SC, Castilla LH (2006) Cbf beta- SMMHC induces distinct abnormal myeloid progenitors able to develop acute myeloid leukemia. Cancer Cell 9:57-68

38. Will B, Zhou L, Vogler TO, Ben-Neriah S, Schinke C, Tamari R, Yu Y, Bhagat TD, Bhattacharyya S, Barreyro L, Heuck C, Mo Y, Parekh S, McMahon C, Pellagatti A, Boultwood J, Montagna C, Silverman L, Maciejewski J, Greally JM, Ye BH, List AF, Steidl C, Steidl U, Verma A (2012) Stem and progenitor cells in myelodysplastic syndromes show aberrant stage-specific expansion and harbor genetic and epigenetic alterations. Blood 120:2076-2086 